\title{
PERBANDINGAN PELUANG PEKERJAAN OLEH MAJIKAN KEPADA BEKAS PENAGIH DADAH DI MALAYSIA (A COMPARATIVE STUDY OF JOB OPPORTUNITY BY EMPLOYEE TO THE FORMER DRUG USERS IN MALAYSIA)
}

Ezarina Zakaria, Fauziah Ibrahim, Salina Nen, Norjana Saim \& Mohd Norahim Mohamed Sani

Pusat Pengajian Psikologi dan Pembangunan Manusia

Fakulti Sains Sosial dan Kemanusiaan, Universiti Kebangsaan Malaysia, (ezaz@ukm.edu.my)

\begin{abstract}
The holistic recovery of drug users depends on total abstinence and a successful community re-integration program. Reintegration program opts for a holistic approach, and one of the indicators used is based on the former drug users ability to stay in long term employment. It is crucial for employers to give employment opportunities to former drug users after they have successfully completed a rehabilitation program. This article aims to discuss the comparison of employer support between groups of Persons under Supervision who have completed the rehabilitation within 6-11 months (K1) programme and those who have undergone a period of rehabilitation within 12-24 months (K2). This quantitative study was conducted using crosssectional design. The study selected 386 Person under Supervision (189 respondents in K1 programmes and 197 respondents in K2) from four main zones of Peninsular Malaysia. The employer support instrument (ESI) created and used in the study consists of 10 major items. Data was analyzed using descriptive analysis such as frequency, mean, mode, median, percentage and standard deviation. The analysis showed no significant difference between the level of employers support for $\mathrm{K} 1$ and $\mathrm{K} 2$ employees. A majority in both groups received moderate support from their employers (75.1\%). Further comparative analysis revealed that K2 received slightly higher employer's support $(75.6 \%)$ than $\mathrm{K} 1(74.6 \%)$ although no noticeable difference regarding supporting level. The findings also bring to light the need to establish
\end{abstract}


mechanisms of relapse prevention and complete recovery of OKP with a focus on reducing the constraints to find job opportunity due to long term "institutionalization," providing a quality job opportunity and strengthening the components of employment offered by employers. The findings of this research provide insight into the potential for total recovery by providing employment with the expectation of former drug users' success in community re-integration.

Keywords: employers support, job opportunity, community re-integration, acceleration rehabilitation, Persons under Supervision

\section{Pengenalan}

Sokongan majikan dalam memberi peluang pekerjaan kepada bekas penagih dadah amat penting bagi menentukan kejayaan tahap kepulihan mereka. Kebiasaannya, individu yang mempunyai rekod penyalahgunaan dadah berhadapan dengan kepayahan untuk mendapatkan pekerjaan sehingga menjejaskan tahap kepulihan dan mendorong mereka untuk kembali semula kepada kehidupan lama dan relaps (Fauziah, Omar, Lukman, Alavi, Sarnon, Nen, \& Subhi, 2011). Terdapat juga dalam kalangan OKP yang nekad menjalankan kegiatan jenayah yang menyalahi undang-undang negara disebabkan gagal mendapatkan pekerjaan bagi menampung keperluan kewangan dan saraan hidup keluarga (Jackson, 1990). Di Malaysia, statistik yang dikeluarkan oleh Agensi Dadah Kebangsaan (AADK) sepanjang bulan Januari hingga Julai 2012 menunjukkan seramai 5,221 orang (92.13\%) penagih yang dikesan adalah mereka yang pada asalnya mempunyai pekerjaan. Namun disebabkan kesalahan dadah, mereka kehilangan pekerjaan dan dihantar untuk menjalani program rawatan dan pemulihan dadah di Cure $\mathcal{E}$ Care Rehabilitation Centre (CCRC).

Keengganan majikan mengambil bekas penagih untuk bekerja telah banyak didokumentasikan. Satu kajian ke atas lebih 3,000 pertubuhan di empat kawasan bandar utama mendapati bahawa lebih 60 peratus daripada majikan menunjukkan bahawa mereka "tidak mungkin" atau "tidak pasti" untuk mengambil individu yang dahulunya mempunyai rekod pernah dipenjarakan untuk bekerja dengan organisasi mereka (Holzer, Raphael, \&Stoll, 2002). Selain stigma yang dikaitkan dengan rekod jenayah, kebimbangan dan persepsi yang menganggap banduan sebagai liabiliti kepada organisasi menjadikan mereka sukar untuk mendapatkan 
pekerjaan. Manakala kajian yang dijalankan oleh Fauziah et al. (2011) pula mendapati $98 \%$ penagih relaps yang terlibat dalam kajiannya menyatakan bahawa mereka menerima tahap sokongan yang sederhana ke tahap yang rendah daripada majikan mereka. Keadaan ini memberi gambaran bahawa kebanyakan majikan sukar untuk memberi kerjasama bagi memberikan peluang kepada Orang Kena Pengawasan (OKP) untuk mendapatkan pekerjaan dan meneruskan kehidupan baru khususnya penagih yang juga bekas banduan. Kebanyakan majikan tidak yakin dengan kebolehan dan komitmen OKP untuk bekerja dengan organisasi mereka.

Kenyataan ini diperkuatkan lagi dengan penemuan kajian yang mendapati sejumlah $78.5 \%$ responden mengakui bahawa kebanyakan majikan tidak yakin untuk mengambil OKP yang telah berjaya menjalani rawatan dan pemulihan untuk kembali bekerja dengan organisasi mereka dan $73.8 \%$ lagi menyatakan bahawa pihak majikan akan memberhentikan mereka sekiranya mendapati diri mereka terlibat dengan dadah. Keputusan kajian ini selari dengan dapatan kajian yang dijalankan oleh Mahmood (2006) yang mendapati $61.7 \%$ majikan akan mengambil tindakan memberhentikan pekerja yang didapati bersalah terlibat dalam aktiviti penyalahgunaan dadah di tempat kerja. Keadaan ini secara tidak langsung telah memberi tekanan dan menjejaskan tahap kepulihan OKP dan mempengaruhi mereka untuk kembali kepada kehidupan lama iaitu dengan menagih semula seperti juga yang diutarakan oleh Mc Coy dan Lai (1997) dan Yunos (1996). Dapatan ini diperkukuhkan lagi dengan hasil kajian seterusnya yang mendapati bahawa terdapat perkaitan yang negatif dan signifikan antara sokongan majikan dengan kecenderungan penagihan relaps $(r=-.193, p<.05)$. Hubungan yang negatif memberi maksud bahawa semakin rendah sokongan majikan kepada penagih maka semakin tinggi kecenderungan mereka untuk kembali relaps. Ini kerana masalah tiada pekerjaan dalam kalangan OKP telah menyebabkan mereka kembali semula ke alam penagihan (Wong, Sheppard, Dallery, Bedient, Robles, Svikis, \& Silverman 2003). Malah pengangguran dalam kalangan penagih berkait rapat secara positif dengan pengambilan semula dadah, kesan yang rendah terhadap rawatan yang diterima dan penglibatan dalam tingkah laku jenayah (Mohd. Azlan \& Mahmood Nazar, 2009; Wong et al. 2003). Hal ini kerana OKP tiada pekerjaan dan sumber kewangan untuk menyara kehidupan mereka dan seterusnya mendorong mereka untuk kembali relaps.

Selain itu, kejayaan memperoleh pekerjaan memainkan peranan dalam mempengaruhi kemampuan OKP untuk kekal bersih daripada 
dadah (Mclellan, McKay, Forman, Cacciola, \& Kemp 2005). Penilaian yang lebih tepat terhadap rawatan luar adalah dengan memperolehi kesan yang diingini seperti mempunyai pekerjaan stabil dan bukan hanya terhad kepada bebas pengaruh dadah mahupun jenayah. Penambahbaikan dalam pekerjaan membawa kepada peningkatan dalam kefungsian sosial yang secara langsung mempengaruhi tingkah laku penagih secara positif. Hasil kajian yang dijalankan oleh Mclellan dan rakan-rakan mendapati bahawa majikan juga merupakan individu yang boleh menentukan kejayaan rawatan dan pemulihan total dalam diri penagih (Mclellan et al. 2005).

Penjelasan dan pemahaman tentang rawatan pemulihan perlu diterangkan kepada majikan kerana ia akan dapat membantu kejayaan proses pemulihan penagih secara lebih holistik. Mohd. Rafidi (2008) menjelaskan bahawa majikan merupakan tempat yang boleh dirujuk untuk membantu dalam penyediaan rancangan pemulihan klien. Pihak majikan perlu diberi tanggungjawab untuk bersama-sama membantu penagih yang telah pulih bebas daripada pengaruh dadah. Beliau turut menjelaskan apabila kurangnya sokongan daripada majikan akan menyebabkan halangan kepada proses rawatan dan pemulihan klien. Keadaan ini mengganggu proses pemulihan untuk menghindari diri klien daripada menggunakan semula dadah. Sikap bias dalam kalangan majikan juga boleh mendorong kepada pengambilan semula dadah dalam kalangan penagih. Oleh itu, sokongan daripada majikan adalah penting kerana ia memainkan peranan dalam mempengaruhi tingkah laku relaps dalam kalangan penagih (Mohd. Azlan \& Mahmood Nazar, 2009). Malah terdapat majikan yang terlibat secara langsung dalam memperkenalkan intervensi seperti "The Therapeutic Workplace" untuk membantu individu yang bebas dadah memasuki dunia pekerjaan. Program ini teah membantu OKP untuk bebas daripada pengaruh dadah (Wong et al., 2003).

Walau bagaimanapun, penilaian terhadap beberapa program intervensi pekerjaan yang memberikan latihan kepada penagih mendapati bahawa kebanyakan peserta (penagih) masih gagal untuk mengekalkan keadaan kepulihan walaupun telah mendapat sokongan daripada majikan dan diberikan peluang pekerjaan (Carpenedo, Needham, Knealing, Kolodner, Fingerhood, Wong, \& Silverman, 2007). Hasil penilaian terhadap 1433 orang bekas penagih dadah yang menganggur selepas mendapatkan rawatan selama enam bulan mendapati bahawa mereka (OKP) hanya dapat mengekalkan kepulihan dan bebas daripada pengaruh dadah antara 12 hingga 18 bulan sahaja walaupun telah mendapat sokongan daripada majikan dengan diberikan peluang pekerjaan (Carpenedo et al., 2007). Di 
samping itu, terdapat penemuan kajian yang menjelaskan bahawa majikan kurang menerima OKP untuk bekerja di organisasi mereka disebabkan oleh kemahiran OKP yang tidak sesuai serta tidak memiliki kemahiran sepertimana yang dikehendaki oleh majikan. Kurang kemahiran ini dipercayai kerana mereka telah lama berada dalam dunia penagihan dan gagal untuk meningkatkan kemahiran yang telah sedia ada. Keadaan ini seterusnya menyebabkan majikan tidak dapat mengambil mereka untuk bekerja dan menambahkan lagi keenganan majikan untuk memberikan peluang pekerjaan kepada OKP.

Kajian terdahulu mengesahkan sokongan majikan banyak tertakluk kepada sejauhmana OKP berupaya kekal dalam kepulihan selepas menjalani rawatan pemulihan di institusi. Namun timbul persoalan sejauhmana majikan meyokong pengambilan OKP yang menjalani tempoh pemulihan dan rawatan yang berbeza-beza. Persoalan tentang kumpulan OKP yang mana lebih mendapat kepercayaan dan sokongan majikan untuk diambil bekerja juga perlu diberi perhatian. Justeru bagi menjawab persoalan yang timbul, satu kajian perbandingan telah dijalankan bagi mengenalpasti bagaimana tahap sokongan majikan terhadap OKP yang menjalani pemulihan dalam tempoh enam hingga 11 bulan dan 12 hingga 24 bulan.

\section{Tujuan Kajian}

Kajian ini dijalankan bertujuan untuk mengukur perbandingan tahap sokongan majikan antara Orang Kena Pengawasan (OKP) yang menjalani program penyingkatan CCRC dalam tempoh 6-11 bulan (K1) dengan OKP yang menjalani pembebasan daripada CCRC antara 12-24 bulan (K2).

\section{Metod Kajian}

Kajian ini menggunakan pendekatan metodologi berbentuk tinjauan keratanlintang (cross-sectional survey) secara kuantitatif dan dianalisis dengan menggunakan ujian deskriptif. Malhotra, Sham, \& Crsip (1996) menyatakan bahawa reka bentuk keratan-lintang melibatkan kaedah pengumpulan data terhadap satu jenis sampel daripada populasi yang dikaji secara sekali sahaja berdasarkan kepada atribut responden yang sedia ada. Analisis deskriptif merupakan statistik yang digunakan untuk menghuraikan ciri-ciri variabel (Chua, 2012). Analisis ini digunakan untuk mengukur objektif kajian. 


\section{Penganalisaan Data}

Data kajian telah dianalisis dengan menggunakan 'Statistical Package for the Social Science for Windows' (SPSS for Windows).

\section{Analisis deskriptif}

Analisis deskriptif merupakan analisis statistik seperti frekuensi, min, mod, median, peratusan dan sisihan piawai yang digunakan untuk yang menghuraikan ciri-ciri variabel (Chua, 2012). Analisis ini juga digunakan untuk mengukur tahap perbandingan sokongan majikan antara klien yang menjalani program penyingkatan CCRC dalam tempoh 6-11 bulan dengan klien yang menjalani pembebasan antara 12-24 bulan. Bagi mengukur perbandingan tahap sokongan majikan terhadap dua kumpulan berkenaan, alat ukuran sokongan majikan (SM) yang dibina oleh Fauziah et al. (2015) dan mengandungi 10 soalan berkaitan dengan sokongan majikan terhadap responden telah digunakan. Jenis item yang digunakan dalam bahagian ini adalah berbentuk Likert empat skala dengan pilihan disusun mengikut kesesuaian iaitu (1) sangat tidak setuju, (2) tidak setuju, (3) setuju dan (4) sangat setuju. Nilai kebolehpercayaan untuk skala yang digunakan dalam kajian ini adalah 0.686. Perbandingan tahap sokongan majikan antara klien yang menjalani program penyingkatan CCRC dalam tempoh 6-11 bulan dengan klien yang menjalani pembebasan antara 12-24 bulan diukur berpandukan kepada jadual interpretasi skor min seperti Jadual 1 berikut:-

Jadual 1: Jadual interpretasi skor min terhadap tahap sokongan majikan antara klien yang menjalani program penyingkatan CCRC dalam tempoh 6-11 bulan dengan klien yang menjalani pembebasan antara 12-24 bulan

\begin{tabular}{ll}
\hline Skor $\min$ & Interpretasi skor min \\
\hline$<.20$ & Tahap rendah \\
$2.01-3.00$ & Tahap sederhana \\
$3.01-4.00$ & Tahap tinggi
\end{tabular}

\section{Populasi dan sampel kajian}

Dalam kajian ini, populasi kajian merujuk kepada OKP yang sedang menjalani program pengawasan oleh Agensi Anti-Dadah Kebangsaan. Kesemua mereka yang terlibat dalam kajian ini terdiri daripada (1) klien yang menjalani program penyingkatan CCRC dalam tempoh 6-11 bulan dan (2) klien yang 
telah menjalani pembebasan antara 12-24 bulan. Persampelan rawak bertujuan digunakan untuk memilih ahli-ahli iaitu OKP yang sedang mengikuti program pengawasan AADK di seluruh Semenanjung Malaysia dengan pecahan seperti berikut:

\begin{tabular}{|c|c|c|c|c|}
\hline & \multirow[t]{2}{*}{ Zon } & \multirow[t]{2}{*}{ Tempat } & \multicolumn{2}{|c|}{ Responden } \\
\hline & & & K1 & K2 \\
\hline 1 & Selatan & $\begin{array}{l}\text { AADK Johor } \\
\text { AADK N. Sembilan }\end{array}$ & $\begin{array}{l}25 \\
25\end{array}$ & $\begin{array}{l}28 \\
25\end{array}$ \\
\hline 2 & Timur & $\begin{array}{l}\text { AADK Kelantan } \\
\text { AADK Terengganu }\end{array}$ & $\begin{array}{l}15 \\
23\end{array}$ & $\begin{array}{l}13 \\
25\end{array}$ \\
\hline 3 & Tengah & $\begin{array}{l}\text { AADK W. Persekutuan KL } \\
\text { AADK Selangor }\end{array}$ & $\begin{array}{l}25 \\
24 \\
\end{array}$ & $\begin{array}{l}28 \\
26\end{array}$ \\
\hline 4 & Utara & $\begin{array}{l}\text { AADK P.Pinang } \\
\text { AADK Kedah }\end{array}$ & $\begin{array}{l}26 \\
26\end{array}$ & $\begin{array}{l}26 \\
26\end{array}$ \\
\hline & \multicolumn{2}{|c|}{ JUMLAH SAMPEL } & 189 & 197 \\
\hline & & & \multicolumn{2}{|c|}{386} \\
\hline
\end{tabular}

Nota: K1= Klien menjalani rawatan penyingkatan CCRC 6-11 bulan K2 = Klien menjalani pembebasan CCRC 12-24 bulan

\section{Proses Pengumpulan Borang Soal Selidik}

Pengedaran borang soal selidik kajian kemudiannya telah dijalankan secara rawak setelah mendapat kebenaran menjalankan kajian daripada pihak AADK.

Sewaktu kerja-kerja pengutipan data dilakukan, penyelidik telah dibantu oleh Pegawai Pemulihan AADK untuk menjalankan kerja-kerja pengedaran dan pengutipan data. Kaunselor dan pegawai-pegawai pemulihan AADK yang terlibat terlebih dahulu diberikan penerangan dan taklimat ringkas berkaitan kaedah pengumpulan data oleh penyelidik. Seterusnya, Pegawai pemulihan AADK telah mengumpulkan OKP yang sedang mengikuti program pengawasan dalam komuniti mengikut bilangan yang dikehendaki dan kemudiannya mengasingkan mereka kepada dua kumpulan seperti berikut:-

1. OKP yang boleh membaca, dan

2. OKP yang tidak boleh membaca.

Tujuan pengasingan kumpulan berkenaan adalah untuk memudahkan proses melengkapkan borang soal selidik. Bagi OKP yang boleh membaca mereka telah menjawab setiap soalan pada borang soal selidik yang diedarkan secara sendirian dan diawasi oleh Pegawai Pemulihan AADK dan pasukan 
penyelidik sendiri. Manakala bagi kumpulan OKP yang tidak tahu membaca, Pegawai Pemulihan AADK telah ditempatkan di dalam kumpulan mereka untuk membantu membacakan satu persatu soalan yang disediakan dengan tujuan memudahkan proses menjawab soalan. Dalam masa yang sama, pengkaji juga bertindak mengawasi responden sewaktu mereka menjawab soal selidik bagi membolehkan mereka bertanya sekiranya terdapat soalansoalan yang masih tidak difahami. Bagi mendapatkan jumlah borang soal selidik yang tepat, pasukan penyelidik telah memeriksa setiap helaian pada borang soal selidik sewaktu pengutipan borang soalselidik dijalankan. Ia bertujuan memastikan setiap responden mengisi borang soal selidik dengan sempurna dan lengkap. Sekiranya terdapat mana-mana borang yang didapati tidak diisi dengan lengkap, pasukan penyelidik akan memulangkan semula kepada responden dan memastikan mereka menjawab soalan dengan bantuan daripada Pegawai Pemulihan AADK.

\section{Hasil Kajian dan Perbincangan}

Berdasarkan analisis aspek sokongan majikan, hasil kajian menunjukkan bahawa tidak terdapat perbezaan yang ketara antara responden yang menjalani program penyingkatan CCRC dalam tempoh 6-11 bulan dengan responden yang menjalani pembebasan antara 12-24 bulan (Jadual 2). Ini kerana analisis kajian menunjukkan kedua-dua kumpulan ini majoritinya menerima tahap sokongan yang sederhana daripada majikan mereka $(75.1 \%)$. Daripada tahap kesederhanaan tersebut, analisis kajian menunjukkan responden yang menjalani pembebasan antara 12-24 bulan menunjukkan tahap sokongan majikan yang lebih tinggi (75.6\%) peratusannya berbanding dengan responden yang menjalani penyingkatan CCRC dalam tempoh 6-11 bulan (74.6\%), walaupun kedua-dua bilangan tersebut tidak begitu ketara. Penemuan ini, besar kemungkinan didorong oleh keyakinan majikan yang lebih tinggi dalam menerima OKP sebagai pekerja sekiranya mereka menjalani tempoh pemulihan lebih lama iaitu dalam tempoh 12-24 bulan berbanding 611 bulan. Lebih lama tempoh menjalani rawatan pemulihan di CCRC memberi makna bahawa OKP lebih lama berjaya bebas dadah dan lebih meyakinkan para majikan untuk mengambil mereka bekerja semula.

Hasil kajian ini selari dengan kajian terdahulu oleh Carpenedo et al., (2007) yang melaporkan walaupun OKP diberikan peluang pekerjaan, namun majikan mendapati mereka hanya dapat mengekalkan kepulihan dan bebas daripada pengaruh dadah antara 12 hingga 18 bulan sahaja. Keyakinan majikan terhadap intervensi kepulihan melepasi tempoh 24 bulan menjadi 
justifikasi mengapa tahap sokongan majikan lebih tinggi (75.6\%) peratusannya kepada responden yang menjalani pembebasan antara 12-24 bulan berbanding dengan responden yang menjalani penyingkatan CCRC dalam tempoh 6-11 bulan (74.6\%) seperti yang ditemui oleh kajian ini. Walaupun kedua-dua kumpulan ini tidak ketara perbezaannya namun justifikasi keyakinan majikan ini perlu diberi perhatian dalam usaha meningkatkan kadar kebolehgajian dan keupayaan diterima bekerja dalam kalangan OKP sebelum mereka dipilih untuk penyingkatan tempoh dalam pemulihan.

Jadual 2: Analisis Perbandingan Tahap Sokongan Majikan

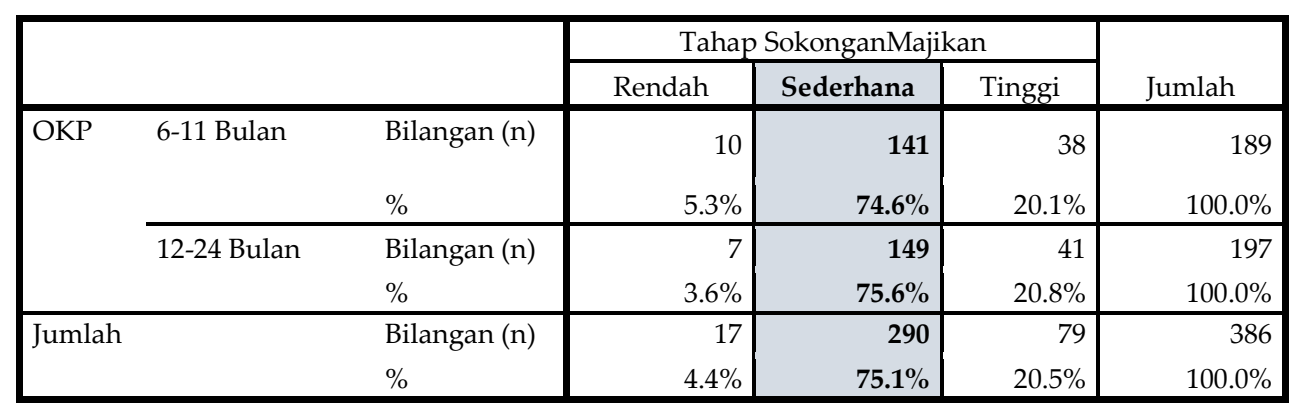

Berdasarkan analisis domain sokongan majikan sepertimana Jadual 3, hasil kajian mendapati majoriti responden (51.3\%) mengakui bahawa kebanyakan mereka mudah mendapat pekerjaan walaupun mereka OKP (Item 1). Daripada keseluruhan responden, hasil kajian ini juga mendapati kebanyakan responden $(74.3 \%)$ mengakui bahawa majikan memberikan layanan yang adil kepada mereka (Item 2), dibayar gaji yang sesuai dengan kelayakan dan kemahiran kerja yang mereka miliki (84.4\%) (Item 4), masih mahu memberi peluang pekerjaan kepada diri mereka walaupun mengetahui bahawa mereka masih berada dalam tempoh pemulihan di bawah pengawasan AADK (74.3\%) (Item 3). Selain itu, kajian juga mendapati majoriti responden $(71.5 \%)$ mengakui bahawa majikan masih mahu memberikan mereka peluang pekerjaan walaupun mengetahui mereka mempunyai rekod penagihan dadah (Item 9). 
Jadual 3: Sokongan Majikan Responden Mengikut Item

\begin{tabular}{|c|c|c|c|c|c|}
\hline Bil & Pernyataan & 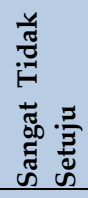 & 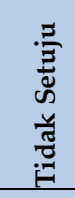 & 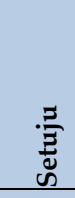 & 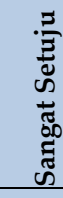 \\
\hline & \multicolumn{5}{|l|}{ Sokongan Majikan } \\
\hline & \multicolumn{5}{|c|}{ Peratus(\%) } \\
\hline 1. & $\begin{array}{l}\text { Saya mudah mendapat pekerjaan walaupun saya bekas } \\
\text { penagih }\end{array}$ & 8.8 & 39.9 & 39.4 & 11.9 \\
\hline 2. & Majikan memberikan layanan kerja yang adil kepada saya & 5.2 & 20.5 & 58.8 & 15.5 \\
\hline 3. & $\begin{array}{l}\text { Majikan memberi peluang pekerjaan walaupun saya masih } \\
\text { dalam tempoh pengawasan }\end{array}$ & 6.2 & 19.4 & 56.7 & 17.6 \\
\hline 4. & $\begin{array}{l}\text { Saya dibayar gaji yang sesuai dengan kelayakan dan } \\
\text { kemahiran kerja yang saya ada }\end{array}$ & 2.1 & 13.5 & 62.4 & 22.0 \\
\hline 5. & $\begin{array}{l}\text { Majikan akan memberhentikan saya kerja sekiranya } \\
\text { mendapati saya terlibat dengan dadah }\end{array}$ & 6.2 & 24.1 & 46.1 & 23.6 \\
\hline 6. & $\begin{array}{l}\text { Kebanyakan majikan tidak yakin untuk mengambil bekas } \\
\text { penagih kembali bekerja }\end{array}$ & 7.0 & 27.7 & 42.2 & 23.1 \\
\hline 7. & Saya merasakan majikan menganggap saya sebagai beban & 15.0 & 49.7 & 26.2 & 9.1 \\
\hline 8. & $\begin{array}{l}\text { Saya mendapat sokongan sosial yang tinggi di tempat kerja } \\
\text { untuk bebas dadah }\end{array}$ & 3.6 & 21.5 & 57.0 & 17.9 \\
\hline 9. & $\begin{array}{l}\text { Majikan masih memberikan saya pekerjaan walaupun saya } \\
\text { mempunyai rekod penagihan }\end{array}$ & 6.5 & 22.0 & 58.0 & 13.5 \\
\hline 10. & Sokongan majikan amat membantu saya untuk bebas dadah & 4.1 & 15.8 & 54.9 & 25.1 \\
\hline
\end{tabular}

Hasil kajian ini bertentangan dengan penemuan kajian terdahulu yang lebih mendokumentasikan penafian majikan terhadap peluang menyediakan pekerjaan bagi OKP seperti penemuan yang diperoleh oleh kajian yang dijalankan oleh Holzer et al. (2002); Mohd Azlan \& Mahmood Nazar (2009) dan Fauziah et al. (2011). Kajian yang dijalankan oleh Holzer dan rakan-rakan (2002) sebagai contoh mendapati bahawa lebih 60 peratus daripada majikan menunjukkan bahawa mereka "tidak mungkin" atau "pasti tidak" mengambil individu yang dahulunya mempunyai rekod pernah dipenjarakan dan OKP untuk bekerja dengan organisasi mereka (Holzer, Raphael, \& Stoll, 2002). Berbeza dengan kajian yang dijalankan oleh Holzer et al. (2002); Mohd Azlan \& Mahmood Nazar (2009) dan Fauziah et al. (2011), hasil analisis kajian ini telah menunjukkan responden yang dikaji menerima sokongan majikan secara positif walaupun mereka merupakan OKP. Sokongan daripada majikan adalah penting kerana ia memainkan peranan dalam mempengaruhi tingkah laku relaps dalam kalangan penagih (Mohd Azlan \& Mahmood Nazar, 2009).

Sokongan positif daripada majikan ini memberikan petunjuk yang positif ke arah pemulihan penagih untuk terus mengamalkan gaya hidup sihat 
tanpa dadah. Keadaan ini disokong dengan dapatan kajian seterusnya yang menunjukkan bahawa seramai $74.9 \%$ dalam kalangan responden bersetuju dan sangat bersetuju dengan pernyataan bahawa mereka mendapat sokongan sosial yang tinggi di tempat kerja untuk bebas daripada pengaruh dadah (Item 8) dan beranggapan bahawa majikan tidak menganggap mereka sebagai suatu beban (64.7\%) (Item 7). Hasil kajian juga mendapati majoriti responden $(69.7 \%)$ menyedari bahawa majikan akan memberhentikan mereka kerja sekiranya mendapati diri mereka terlibat semula dengan dadah (Item 5). Penemuan bagi Item 8, Item 7 dan Item 5 dalam kajian ini adalah selari dengan hasil kajian yang dijalankan oleh Mc Coy \& Lai (1997), Yunos (1996) dan Mohd Rafidi (2008) bagi item 7-8. Penemuan bagi item 5 pula adalah selari dengan kajian yang dijalankan oleh Mahmood (2006). Secara keseluruhannya seramai 80\% dalam kalangan responden mengakui bahawa sokongan majikan amat membantu mereka untuk terus bebas daripada pengaruh dadah (Item 10).

Kajian yang dijalankan oleh Mclellan, McKay, Forman, Cacciola, dan Kemp (2005) telah menjelaskan justifikasi penemuan bagi Item 10 dalam kajian ini. Menurut Mclellan et al. (2005), aspek pekerjaan memainkan peranan dalam mempengaruhi kejayaan untuk kekal bebas daripada pengaruh dadah. Penilaian yang lebih tepat terhadap rawatan luar adalah dengan melihat kesan yang diingini seperti mempunyai pekerjaan selain bebas daripada pengaruh dadah dan juga jenayah. Penambahbaikan dalam pekerjaan membawa kepada peningkatan dalam kefungsian sosial yang mana turut mempengaruhi tingkah laku penagih secara positif. Hasil kajian yang dijalankan oleh Mclellan et al. (2005) ini mengesahkan bahawa majikan juga merupakan individu yang boleh menentukan kejayaan rawatan dan pemulihan terhadap diri penagih.

Penemuan Mclellan dan rakan-rakan (2005) ini telah disokong oleh penemuan kajian yang dijalankan oleh Mohd. Rafidi (2008) yang menjelaskan bahawa pihak majikan perlu diberikan tanggungjawab untuk bersama-sama membantu penagih yang telah pulih bebas daripada pengaruh dadah. Penjelasan dan pemahaman tentang rawatan pemulihan perlu diterangkan kepada majikan kerana ia akan dapat membantu kejayaan proses pemulihan penagih. Mohd. Rafidi (2008) turut menjelaskan bahawa majikan merupakan tempat yang boleh dirujuk untuk membantu dalam penyediaan rancangan pemulihan klien. Berkurangnya sokongan daripada majikan akan menyebabkan halangan kepada proses rawatan dan pemulihan klien. Keadaan ini mengganggu proses pemulihan untuk menghindari diri klien daripada menggunakan semula dadah. Sikap bias dalam kalangan majikan juga boleh mendorong kepada pengambilan semula dadah dalam kalangan penagih. 
Walaupun secara keseluruhan hasil kajian menunjukkan sokongan majikan adalah memuaskan daripada aspek memberi layanan, peluang pekerjaan, pembayaran gaji yang sesuai mengikut kemahiran kerja dan memberikan sokongan sosial yang tinggi di tempat kerja namun hasil kajian mendapati majoriti (65.3\%) responden beranggapan bahawa masih terdapat majikan yang tidak yakin untuk mengambil OKP untuk kembali bekerja (Item 6). Penemuan bagi analisis Item 6 ini didapati selari dengan kajian yang dijalankan oleh Fauziah et al. (2011) dan Fauziah et al. (2015). Menurut Fauziah, et al. (2011) sebanyak $98 \%$ penagih relaps yang terlibat dalam kajiannya menerima tahap sokongan yang sederhana ke tahap yang rendah daripada majikan mereka. Keadaan ini memberi gambaran bahawa kebanyakan majikan sukar untuk memberi kerjasama bagi memberikan peluang kepada OKP untuk mendapatkan pekerjaan dan meneruskan kehidupan baru. Tingkah laku berisiko yang diamalkan oleh responden khususnya menagih dadah telah membatasi kemampuan responden bukan sahaja untuk mendapatkan pekerjaan tetapi juga untuk mereka kekal dalam pekerjaan yang sama bagi satu-satu masa. Penemuan ini selari dengan dapatan kajian Devah (2003), Holzer, Harry, Raphael, dan Stoll (2006), Pager, Devah, Western, dan Bonikowski (2009) dan Rodriguez, Michelle, dan Emsellem (2011). Malah penemuan kajian Holzer et al. (2006) telah mendokumentasikan secara jelas mengenai kecenderungan majikan untuk menolak permohonan pekerjaan oleh bekas banduan dan bekas penagih dadah. Majikan dilaporkan besar kemungkinan tidak mempertimbangkan ataupun akan menolak terus sebarang permohonan yang mempunyai rekod pemulihan. Jelasnya rekod jenayah dan rekod pemulihan berupaya menjadi halangan automatik bagi sebilangan besar OKP mendapatkan pekerjaan khususnya pekerjaan stabil dan berkualiti. Mereka kerap dipecat, susut bilangan minggu bekerja dalam setahun dan penyusutan monetari upah atau upah rendah menyebabkan ramai yang akan memilih untuk bergantung kepada pendapatan daripada kerja jenayah (Rodriguez et al., 2011; The Pew Charitable Trusts, 2010). Secara timbal balik, bekas penagih yang tidak dapat kekal dalam pekerjaan stabil akan terdorong terlibat jenayah yang seterusnya menambahkan lagi penolakan majikan kepada mereka atas alasan mempunyai rekod jenayah dan rekod penagih.

Perlabelan ke atas bekas penagih dadah seperti yang ditemui dalam kajian juga sebenarnya telah sekian lama didokumentasikan (Duran, Plotkin, Potter, \& Rosen, 2013; Solomon, 2012; Conklin, 1995). Pengalaman "hidup diinstitusikan" dalam tempoh masa yang agak lama adalah juga antara faktor yang boleh mengurangkan peluang pekerjaan kerana wujudnya jurang pengetahuan dan juga kemahiran. Sebagai contoh, pastinya ramai OKP yang kurang kompeten 
dengan penggunaan teknologi malumat dalam pekerjaan. Mereka kurang pengetahuan berkenaan teknologi baru dan kurang peka kepada perkembangan terkini bidang tugas di lapangan. OKP tidak memperolehi akses kepada internet, email atau laman sesawang sepanjang tempoh pemulihan. Ini mengurangkan potensi dalam menarik minat majikan agar mengambil mereka bekerja.

Seterusnya pengalaman "hidup diinstitusikan" boleh menyuburkan sikap anti-sosial semasa berada di pusat pemulihan dadah kerana gaya hidup antisosial inilah yang menjadi medium untuk mereka bertahan sepanjang tempoh hukuman pemulihan (Solomon, 2012). Acuan begini diperolehi selepas diinstitusikan dan selalunya menghalang OKP ini untuk bertahan dalam pekerjaan selepas dibebaskan. Impak jangka panjang yang lebih negatif adalah apabila OKP menjadi kurang upaya untuk membina kehidupan prososial selepas dibebaskan. Kehidupan prososial mengajar individu untuk refleks tentang kebajikan orang lain serta berfikir bagaimana memberi faedah semula kepada komuniti. Bagi konteks kajian ini, kehidupan prososial difahami sebagai kehidupan dengan peluang pekerjaan stabil yang mengajar OKP bertingkah laku mematuhi undang-undang dan membina hubungan sosial yang positif selepas dibebaskan.

Kajian ini mencadangkan dua mekanisme utama mencegah keterlibatan semula OKP dalam penagihan menggunakan strategi pekerjaan stabil. Matlamat akhir pencapaian mekanisme adalah integrasi semula OKP ke dalam komuniti. Mekanisme pertama adalah dengan memperkukuhkan komponen dalam program pekerjaan dengan meningkatkan kesediaan untuk bekerja serta pengekalan OKP dalam pekerjaan yang stabil. Keduanya, membangunkan prinsip-prinsip penyampaian perkhidmatan melibatkan kerjasama pelbagai agensi bagi mengurangkan relaps seiring dengan pengekalan OKP dalam pekerjaan. Mekanisme kedua merupakan kaedah atau terma kerja (working term) bagi mencapai mekanisme pertama yang dicadangkan.

\section{Mekanisme 1: Pengukuhan komponen dalam program penyediaan pekerjaan}

Pekerjaan bukan sahaja memenuhi keperluan kewangan tetapi juga memberi peluang kepada seseorang individu menjadi produktif, berupaya menyumbang dan mudah diterima secara sosial oleh komuniti. OKP yang memperolehi pekerjaan juga cenderung membina jaringan sokongan sosial dan keyakinan diri yang tinggi. Malah pekerjaan juga menjadi agen kawalan sosial tidak formal apabila tempat kerja menyediakan kondisi semulajadi yang mencegah tingkah laku anti-sosial. Peraturan serta disiplin di tempat kerja mampu mengawal OKP daripada terlibat dengan tingkah laku berisiko dan mengelak 
daripada bercampur dengan aktor sosial yang mendorong mereka terlibat semula dalam jenayah. Selain bertindak sebagai kawalan sosial, pekerjaan juga memberi laluan kepada OKP untuk berhubung dengan komuniti. Individu yang membina rasa kebergantungan dan perapatan dengan institusi sosial komuniti seperti keluarga, sekolah atau setting pekerjaan telah dibuktikan lebih mudah mematuhi norma sosial komunitinya.

Walau bagaimanapun, penyediaan peluang pekerjaan sahaja tidak mencukupi dalam mengurangkan residivis. Pekerjaan yang berkualiti rendah (under-employment) sebenarnya menjadi salah satu faktor criminogenic yang sama beratnya dengan pengangguran itu sendiri. Apabila OKP hanya mampu memperolehi pekerjaan yang tidak stabil dan berkualiti rendah, mereka akan cenderung terus terlibat dengan penagihan dan juga jenayah. Ini kerana kesan jangka panjang pekerjaan berkualiti rendah adalah menyamai kesan negatif pengangguran itu sendiri. Maka, penyediaan kerja yang berkualiti dan stabil perlu diberi perhatian khusus bagi meningkatkan kepulihan total OKP.

Pekerjaan yang mempunyai kualiti boleh diukur daripada gunapakai kemahiran dan bakat OKP secara maksima, kecukupan gaji dalam memenuhi keperluan hidup, kepuasan bekerja, keadaan persekitaran tempat kerja dan jam bekerja. Pekerjaan yang berupah kecil dan memerlukan kemahiran yang rendah selalunya mempunyai potensi yang juga rendah untuk kemajuan mobiliti sosial bekas penagih.

Mekanisme 2: Membangunkan prinsip dalam penyampaian perkhidmatan pekerjaan dengan kerjasama inter-agensi

Kaedah bagaimana sesuatu program diimplementasikan atau cara perkhidmatannya disampaikan kepada kumpulan sasar akan memberi impak kepada kepulihan total OKP. Terdapat lima (5) prinsip asas yang difikirkan sesuai dalam implementasi program persediaan pekerjaan untuk OKP. Penyampaian perkhidmatan bagi penyediaan program pekerjaan yang boleh digunapakai oleh agensi berkepentingan dalam pemulihan dadah perlu mementingkan lima prinsip berikut;

i. Hubungan/Ikatan: menitikberatkan hubungan mentoring dan interaksi antara majikan dengan OKP khususnya bagi mengubah pemikiran serta tingkah laku antisosial

ii. Fasa Masa: menyediakan perkhidmatan/pekerjaan sebaik dibebaskan atau pada permulaan untuk integrasikan OKP dalam komuniti. Ini penting bagi mengetengahkan masalah yang dihadapi oleh penagih sebaik mereka 
dibebaskan. Perkhidmatan perlu segera mengadaptasi perubahan keperluan penagih dari semasa ke semasa

iii. Insentif: meningkatkan motivasi OKP untuk perubahan positif dan meningkatkan prestasi kerja bagi mengekalkan OKP dalam pekerjaan. Insentif dari segi pengiktirafan adalah penting. Apabila OKP didapati berupaya untuk komited kepada kerja dan boleh kekal lama dalam satu-satu pekerjaan, maka insentif berupa pengiktirafan majikan dan rakan sekerja perlu diberikan

iv. Koordinasi : penyedia perkhidmatan perlu berkolaborasi dengan pelbagai agensi seperti AADK, komuniti, agensi pekerjaan, agensi sumber manusia, profesion menolong seperti kaunselor kerjaya, pekerja sosial industri, pekerja sosial komuniti dan pegawai pemulihan dadah bagi memastikan intervensi menyokong pengurangan penagihan berulang, menggalakkan integrasi semula dalam komuniti dan pengekalan dalam pekerjaan stabil

v. Pengurusan dan penstrukturan masa: program seharusnya distrukturkan dengan aktiviti yang efektif dan meminimakan peluang untuk terlibat dengan budaya penagihan. Program diuruskan supaya mengandungi pelbagai pengisian untuk mengurangkan masa senggang supaya OKP tidak terdedah atau bercampur dengan rakan berisiko yang mudah menarik mereka kembali kepada penagihan. Pengurusan dan penstrukuran masa ini penting supaya OKP dapat dipantau daripada faktor risiko walaupun mereka telahpun mempunyai pekerjaan.

Kelima-lima prinsip ini bukan sahaja merekabentuk program pekerjaan malah menyediakan satu struktur bagaimana mengetengahkan keperluan bekas penagih yang berbeza-beza supaya mereka boleh dikekalkan dalam pekerjaan yang berkualiti dan stabil.

\section{Kesimpulan}

Analisis perbandingan tahap sokongan majikan menunjukkan tiada perbezaan ketara antara OKP yang mengikuti program penyingkatan CCRC dalam tempoh 6-11 bulan (K1) dengan OKP yang menjalani pembebasan daripada CCRC antara 12-24 bulan (K2). Kedua-dua kumpulan ini majoritinya menerima tahap sokongan yang sederhana daripada majikan mereka. Namun begitu analisis lanjutan menunjukkan tahap sokongan majikan bagi OKP yang menjalani pembebasan daripada CCRC antara 12-24 bulan adalah lebih tinggi berbanding OKP yang mengikuti program penyingkatan CCRC dalam tempoh 6-11 bulan. Walaupun secara keseluruhan hasil kajian menunjukkan sokongan 
majikan adalah memuaskan daripada aspek memberi layanan, peluang pekerjaan, pembayaran gaji yang sesuai mengikut kemahiran kerja dan memberikan sokongan sosial yang tinggi di tempat kerja namun hasil kajian turut mendapati lebih daripada separuh responden beranggapan bahawa masih terdapat majikan yang tidak yakin untuk mengambil OKP kembali bekerja. Keadaan ini memberi gambaran bahawa kebanyakan majikan sukar untuk bekerjasama bagi memberikan peluang kepada OKP untuk mendapatkan pekerjaan dan meneruskan kehidupan baru. Gambaran ini lebih ketara jika majikan keterlaluan memberi persepsi negatif ke atas tingkah laku berisiko OKP berbanding kemampuan mereka untuk pulih dan menyumbang kepada majikan sepertimana individu lain. Reaksi dan pendirian majikan sebegini telah mengekang OKP bukan sahaja untuk mendapatkan pekerjaan tetapi juga untuk mereka kekal dalam pekerjaan yang sama bagi satu-satu masa.

Jangkaan tentang faktor risiko individu yang akan terlibat dengan penagihan, program kepulihan total dan bagaimana OKP boleh dibantu agar tidak relaps telah menjadi fokus perbincangan para penyelidik dan penyedia perkhidmatan keadilan jenayah sejak sekian lama. Malah aspek utama yang sering diperdebatkan adalah kemampuan OKP untuk berjaya mengikuti program integrasi semula ke dalam komuniti. Intervensi program integrasi semula ini bersifat holistik dan salah satu indikator kejayaannya dinilai daripada kemampuan OKP untuk kekal dalam pekerjaan. Kajian ini mencadangkan dua mekanisme utama mencegah keterlibatan semula OKP dalam penagihan menggunakan strategi pekerjaan stabil. Matlamat akhir pencapaian mekanisme adalah integrasi semula OKP ke dalam komuniti. Mekanisme pertama adalah dengan memperkukuhkan komponen dalam program pekerjaan dengan meningkatkan kesediaan untuk bekerja serta pengekalan OKP dalam pekerjaan yang stabil. Keduanya, membangunkan prinsip-prinsip penyampaian perkhidmatan melibatkan kerjasama pelbagai agensi bagi mengurangkan relaps seiring dengan pengekalan OKP dalam pekerjaan. Mekanisme kedua merupakan kaedah atau terma kerja (working term) bagi mencapai mekanisme pertama yang dicadangkan. Penglibatan multisektoral dan koordinasi antara agensi seperti agensi pemulihan dan rawatan dadah, pendidikan, latihan vokasional, agensi pekerjaan samada pihak kerajaan mahupun swasta dan agensi penguatkuasaan undang-undang adalah amat penting dalam mengaplikasikan kedua-dua mekanisme yang dicadangkan ini. 


\section{Penghargaan}

Kajian ini telah mendapat sokongan dan pembiayaan Agensi Anti-Dadah Kebangsaan (AADK) melalui Geran Penyelidikan kod penyelidikan SK-2014011. Ucapan penghargaan juga ditujukan kepada Agensi Anti-Dadah Kebangsaan dan Fakulti Sains Sosial dan Kemanusiaan, Universiti Kebangsaan Malaysia (UKM) serta semua yang telah terlibat dalam menjayakan kajian ini.

\section{References}

Azlan, M. \& Nazar, M. (2009). Faktor-faktor yang mempengaruhi kecenderungan bekerja penghuni pusat pemulihan penagihan narkotik (PUSPEN). Journal Antidadah Malaysia, 5(1), 1-29

Carpenedo, C.M., Needham, M., Knealing, T.W., Kolodner, K., Fingerhood, M., Wong, C.J., \& Silverman, K. (2007). Professional demeanor of chronically unemployed cocaine-dependent methadone patients in a therapeutic workplace. Substance Use Misuse, 42(7), 1141-1159.

Devah, P. (2003). The Mark of a Criminal Record. American Journal of Sociology 108: 957-960. Retrieved from http://www.princeton.edu

Devah, P., Western, B. \& Bonikowski, B. (2009) Discrimination in a Low-Wage Labor Market: A Field Experiment. American Sociological Review, 74, 777-779. Retrieved from http://www.princeton.edu

Holzer, H. J., Raphael, S., \& Stoll, M. A. (2006). Perceived criminality, criminal background checks, and the racial hiring practices of employers. The Journal of Law and Economics, 49(2), 451-480.

Holzer, H., Raphael, S. \& Stoll, M. (2002). Will Employers Hire Ex-Offenders? Employer Preferences, Background Checks and Their Determinants. In : M. Pattillo, D. Weiman and B. Western. The Impact of Incarceration on Families and Communities,. New York: Russell Sage Foundation.

Fauziah, I., Omar, M., Lukman, Z. M., Alavi, K., Sarnon, N., Nen, S., \& Subhi, N. (2011). Employment barriers against people with drug use histories. Pertanika Journal of Social Science and Humanities, 19(SPEC. ISSUE), 109-114.

Fauziah, I., Zakaria, E., Nen, S., Sani, M. N. M. \& Saim, N. (2015). Perbandingan tahap pengekalan kepulihan antara bekas klien tamat menjalani program penyingkatan CCRC dalam tempoh 6-11 bulan dan 
pembebasan antara 12-24 bulan. Laporan Akhir Penyelidikan Ilmiah Agensi Anti Dadah Kebangsaan. Selangor.

Jusoh, M. R. B. (2008). Rancangan pemulihan klien: Asas dan Aplikasi untuk professional pemulihan. Jurnal Antitdadah Malaysia, 3(1), 57-73.

Mc Coy. C. B \& Lai. S. (1997). No Pain, No Gain, Establishing the Kunming, China, Drug Rehabilitation Center. Journal of Drug Issues, 27 (1), 73-85.

Mclellan, A.T., McKay, J.R., Forman, R., Cacciola, J. \& Kemp, J. (2005). In Reconsidering the evaluation of addiction treatment: from retrospective follow-up to concurrent recovery monitoring. Addicition, 100(4), 447-458.

Mohamed, M. N. (2006). Policy and Tolerance Towards Substance Use and Abuse in Malaysian Organisations. International Journal on Multicultural Societies, 13(2), 41-74.

Mohamed, Y. P. (1996). Dilema, Pengalaman dan Prospek Bekas Penagih Dadah. Kertas Kerja Seminar Dari Institusi Pemulihan Ke Pangkuan Masyarakat, Anjuran Yayasan Pencegahan Jenayah Malaysia. Hotel Crown Princess, Ogos 1996.

Piaw, C. Y. (2012). Asas Statistik Penyelidikan. Kuala Lumpur: Mc Graw Hill Sdn. Bhd.

Rodriguez, M. N., \& Emsellem, M. (2011). 65 Million "Need Not Apply": The Case for Reforming Criminal Background Checks for Employment. New York, National Employment Law Project, March 2011.

Solomon, A. L. (2012). In search of a job: Criminal records as barriers to employment. NIJ Journal, 270, 42-51.

Wong, C. J., Sheppard, J. Dallery, J., Bedient, G. Robles, E. Svikis, D., \& Silverman, K. (2003). Effect of reinforce magnitude on data-entry productivity in chronically unemployed drug abusers participating in a therapeutic workplace. Experimental and Clinical Psychopharmacology, 11(1), 46-55. 